\title{
INTERAKSI LEVERAGE DAN PROFITABILITAS TERHADAP NILAI PERUSAHAAN MELALUI DIVIDEND POLICY
}

\author{
Ni Luh Anik Puspa Ningsih ${ }^{1 *}$ Made Pratiwi Dewi ${ }^{2}$ \\ ${ }^{12}$ Faculty of Economic and Bussiness, Universitas Warmadewa, Denpasar, Bali-Indonesia \\ *kinapuspa168@gmail.com \\ anik@,warmadewa.ac.id
}

\section{How to cite (in APA style):}

Puspaningsih, Ni ,Luh ,Anik \& Dewi, Made, Pratiwi (2021). Interaksi Leverage Dan Profitabilitas Terhadap Nilai Perusahaan Melalui Dividend Policy. Warmadewa Management and Business Joural, $3(1)$ pp.1-11

\begin{abstract}
Firm value is a reflection of company performance which is explicitly shown through share prices. The stock price is one of the parameters for investors in investing. The higher the stock price, the better the company's performance. This study aims to analyze the interaction of firm value with other financial variables as reflected in the company's financial statements, namely leverage, profitability and dividend policy, which are also considered by investors in long-term investment. The population in this study were Food and Beverages companies on the IDX from 2017 to 2019. The population of this study was 31 Food and Beverages companies, the sampling technique using purposive sampling method was obtained as many as 19 sample companies. Data analysis using path analysis techniques. The findings of this study: (1) Leverage has a positive and significant effect on firm value, (2) Leverage has a negative and significant effect on dividend policy. (3) Profitability has a positive and significant effect on firm value, (4) Profitability has a positive and significant effect on dividend policy, (5) Dividend policy has a positive and insignificant effect on firm value. (6) Leverage has a positive and significant effect on firm value through dividend policy mediation. (7) Profitability has a positive and significant effect on firm value through dividend policy mediation.
\end{abstract}

Keywords: Leverage, Profitability, Dividend Policy, Company Value, Food and Beverages

\begin{abstract}
Abstrak
Nilai perusahaan merupakan cerminan kinerja perusahaan yang secara eksplisit ditunjukkan melalui harga saham. Harga saham menjadi salah satu parameter investor dalam berinvestasi. Semakin tinggi harga saham mencerminkan kinerja perusahaan semakin baik. Penelitian ini bertujuan untuk menganalisis interaksi nilai perusahaan dengan variabel keuangan lain yang tercermin dalam laporan keuangan perusahaan yaitu leverage, profitabilitas dan dividend policy (kebijakan dividen) yang juga menjadi pertimbangan investor dalam investasi jangka panjang. Populasi dalam penelitian ini adalah perusahaan Food and Beverages di BEI dari tahun 2017 hingga 2019. Populasi penelitian ini sebanyak 31 perusahaan Food and Beverages, teknik sampling dengan metode purposive sampling diperoleh sebanyak 19 perusahaan sampel. Analisis data menggunakan teknik path analysis. Temuan penelitian ini :
\end{abstract}


(1) Leverage berpengaruh positif dan signifikan terhadap nilai perusahaan, (2) Leverage berpengaruh negatif dan signifikan terhadap kebijakan deviden. (3) Profitabilitas berpengaruh positif dan signifikan terhadap nilai perusahaan, (4) Profitabilitas berpengaruh positif dan signifikan terhadap kebijakan deviden, (5) Kebijakan Deviden berpengaruh positif tidak signifikan terhadap nilai perusahaan. (6) Leverage berpengaruh positif dan signifikan terhadap nilai perusahaan melalui mediasi kebijakan deviden. (7) Profitabilitas berpengaruh positif dan signifikan terhadap nilai perusahaan melalui mediasi kebijakan deviden.

Kata Kunci: Leverage, Profitabilitas, Dividend Policy, Nilai Perusahaan, Food and Beverages

\section{PENDAHULUAN}

Era globalisasi semakin meningkatkan persaingan antar perusahaan di Indonesia. Perusahaan dituntut untuk semakin mengoptimalkan nilai (value) dan kinerja (performance) (Arifin, 2016). Nilai perusahaan merupakan cerminan kinerja perusahaan yang secara eksplisit ditunjukkan melalui harga saham. Harga saham menjadi salah satu parameter investor dalam berinvestasi. Semakin tinggi harga saham mencerminkan kinerja perusahaan semakin baik.

Harga saham di Bursa Efek Indonesia senantiasa mengalami pergerakan yang statis. Fluktuasi pergerakan harga saham ini merupakan indikasi perkembangan investor dalam berinvestasi. Dari segi perspektif investor, penilaian terhadap suatu saham dilhat dari kinerja keuangan dan non keuangan dan sisi keuntungan yang terus meningkat. Minat investor dalam menentukan investasinya terhadap suatu emiten menimbulkan efek psikologis pasar yang dapat menekan kondisi teknikal jual beli saham (Fahmi 2014:331).

Aktivitas trading, supply and demand terhadap suatu saham akan menentukan besaran fluktuasi perubahan harga saham. Secara general, aktivitas trading di Bursa Efek Indonesia terlihat pada fluktuasi Indeks Harga Saham Gabungan (IHSG)

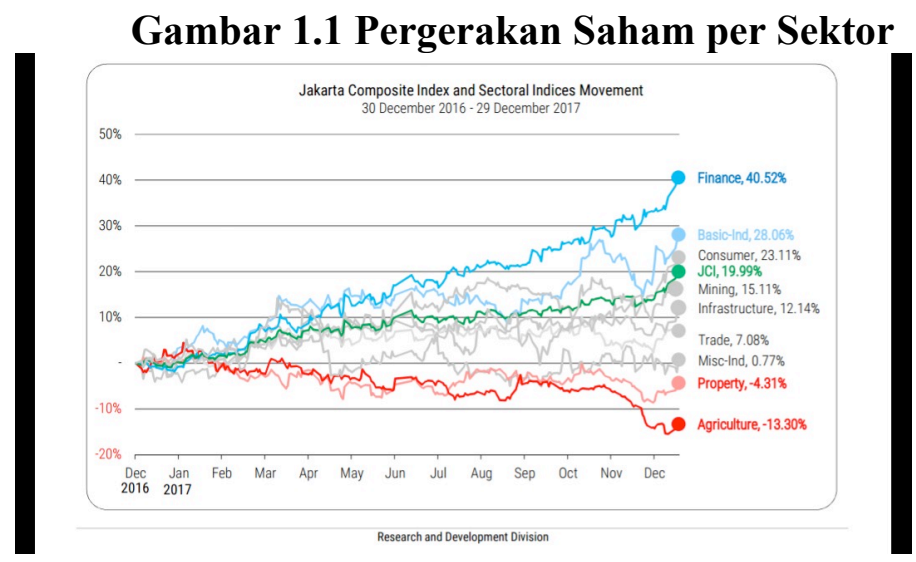

Sumber: www. idx.co.id (2017)

Optimalisasi nilai perusahaan dipengaruhi oleh faktor internal dan eksternal. Faktor internal diantaranya leverage, profitabilitas dan dividend policy. Kebutuhan pembayaran kembali utang perusahaan juga berpengaruh terhadap kemampuan perusahaan untuk membayar deviden (Wiagustini, 2014 : 288). Interaksi ketiga variabel keuangan ini tidak dapat di lepaskan dari peran serta manajer perusahaan. Penting memperhatikan kesejahteraan stakeholder (pemilik dan manajer perusahaan) untuk menghindari terjadinya agency conflict dan optimalisasi nilai perusahaan dapat tercapai.

Perusahaan Food and Beverages menjadi pilihan menarik bagi calon investor. Kinerja sejumlah emiten Food and Beverages mengalami perbaikan pada semester I tahun 2017 
karena laba yang naik dibandingkan periode pertama tahun lalu. Diantaranya PT Indofood Sukses Makmur Tbk (INDF) mencatat kenaikan laba dari sebelumnya Rp 2,23 triliun menjadi $\mathrm{Rp} 2,27$ triliun. Peningkatan positifnya harga komoditas, mendorong beberapa emiten di sector ini kembali bergerak positif. Peningkatan konsumtif memberikan dampak pendukung pergerakan laba perusahaan. Kontrasnya beberapa emiten justru mengalami perlambatan di tahun ini, tidak semua emiten mengalami peningkatan di tahun 2017, diantaranya secara eksternal karena adanya persaingan antar perusahaan yang semakin ketat dan memanas yang melibatkan berbagai merek lokal maupun impor (www.idx.co.id)

Penelitian ini secara spesifik mengkaji aspek internal (finansial) perusahaan. Adapun permasalah dalam penelitian ini, bagaimana pengaruh leverage dan profitabilitas terhadap nilai perusahaan dengan peran mediasi dividend policy?

\section{TELAAH LITERATUR DAN KAJIAN PUSTAKA Signaling Theory}

Teori signaling menyatakan bahwa perusahaan yang berkualitas baik dengan sengaja akan memberikan sinyal pada pasar dengan demikian pasar diharapkan dapat membedakan perusahaan yang berkualitas baik dan buruk. Dividen memberikan informasi atau isyarat mengenai keuntungan perusahaan karena pembayaran dividen akan meningkatkan keyakinan akan keuntungan perusahaan. Jika perusahaan memiliki sasaran rasio pembayaran dividen yang stabil selama ini dan perusahaan dapat meningkatkan rasio tersebut, para investor akan percaya bahawa manajemen mengumumkan perubahan positif pada keuntungan yang diharapkan perusahaan. Isyarat yang diberikan kepada investor adalah bahwa manajemen dan dewan direksi sepenuhnya merasa yakin bahwa kondisi keuangan lebih baik dari pada yang direfleksikan pada harga saham (Ross, 1977).

\section{Dividend Irrelevand Theory}

Dalam kondisi keputusan investasi yang given, pembayaran deviden tidak berpengaruh terhadap kemakmuran pemegang saham (Miller \& Modigliani, 1961). Nilai perusahaan ditentukan oleh earning power dari asset perusahaan (Wiagustini 2014:294). Selanjutnya, (Miller \& Modigliani, 1961) menyatakan bahwa kebijakan deviden tidak berdampak pada harga saham maupun biaya modal suatu perusahaan, melainkan hanya ditentukan oleh profitabilitas dasar dan risiko bisnisnya. Dengan kata lain nilai perusahaan hanya bergantung pada laba yang dihasilkan oleh asetnya, bukan pada bagaimana laba itu dipecah antara dividen dan laba ditahan (Brigham \& Houston 2019:58).

\section{Bird-in-the Hand Theory}

Apabila proporsi pembagian dividen menurun maka akan mengakibatkan kenaikan biaya ekuitas (Litner et al., 1956). Investor lebih yakin terhadap penerimaan dan pembagian deviden dibandingkan dengan kenaikan modal (capital gain) yang dihasilkan laba tersebut (Wiagustini 2014:296). Secara khusus Gordon dan Lintner berpendapat bahwa ekuitas akan turun seiring meningkatnya pembayaran dividen karena investor lebih tidak pasti menerima keuntungan modal yang dihasilkan dari menahan saldo laba dibandingkan dengan menerima deviden (Brigham \& Houston 2019:59).

\section{Tax Differential Theory}

Investor lebih suka untuk menerima capital gain yang tinggi dibanding dengan deviden tinggi. Dengan kata lain investor mengkehendaki perusahaan untuk menahan laba setelah pajak dan dipergunakan untuk pembiayaan investasi daripada pembayaran deviden 
dalam bentuk kas (Litzenberger \& Ramaswamy, 1979). Hal ini berkaitan dengan pajak pendapatan perseorangan. Pendapat yang relevan bagi investor adalah pendapatan setelah pajak, sehingga keuntungan yang disyaratkan juga setelah pajak. investor akan mensyaratkan tingkat keuntungan setelah pajak yang lebih tinggi terhadap saham yang memiliki dividend yield yang tinggi daripada saham dengan dividend yield yang rendah. Sehingga perusahaan disarankan untuk menentukan dividend payout ratio yang rendah atau bahkan tidak membagikan dividen.

\section{Nilai Perusahaan}

Nilai perusahaan merupakan kinerja perusahaan yang dicerminkan oleh harga saham yang dibentuk oleh permintaan dan penawaran pasar modal yang merefleksikan penilaian masyarakat terhadap kinerja perusahaan (Harmono, 2014:233). Adapun alat ukur nilai perusahaan adalah Price to Book Value (PBV). PBV adalah rasio yang menunjukkan apakah harga saham yang diperdagangkan overvalued (di atas) atau undervalued (di bawah) nilai buku saham tersebut (Fakhruddin dan Hadianto, 2008 : 27), (Noerirawan \& Muid, 2012).

\section{Kebijakan Dividen}

Kebijakan dividen merupakan salah satu yang mempengaruhi nilai perusahaan. Kebijakan dividen terkait dengan suatu keputusan laba yang diperoleh Perusahaan akan dibagikan kepada pemegang saham sebagai dividen atau ditahan dalam bentuk laba ditahan guna pembiayaan investasi dimasa datang (Sartono, 2015:281).

\section{Leverage}

Leverage merupakan kebijakan yang dialokasikan dalam bentuk invetasi dana atau memperoleh sumber dana dari pihak eskternal yang digunakan membiayai beban perusahaan (Fakhrudin (2008:109). Rasio leverage dapat diukur salah satunya dengan Debt To Equity Ratio (DER). DER merupakan perbandingan antara total utang dengan total modal sendiri yang dimiliki perusahaan, yang akan dipergunakan untuk pengembalian utang jangka panjang dalam Perusahaan (Kasmir, 2014:157).

\section{Profitabilitas}

Profitabilitas merupakan salah satu indikator kinerja perusahaan. Profitabilitas merupakan kemampuan perusahaan untuk mendapatkan laba atau keuntungan dalam melakukan manajemen perusahaan. Rasio Profitabilitas dapat diukur dengan beberapa indikator diantaranya Return On Assets (ROA). ROA merupakan kemampuan menghasilkan laba bersih dengan semua aktiva yang dimiliki oleh perusahaan (Sartono, 2015:229)

\section{Leverage, Kebijakan Deviden dan Nilai Perusahaan}

Leverage mencerminkan proporsi besarmya total hutang jangka panjang dengan modal sendiri. Hutang yang semakin besar menyebabkan semakin besar kewajiban yang harus dibayar oleh perusahaan (Mehta, 2012). Semakin besar hutang akan menyebabkan prioritas perusahaan untuk membayar deviden akan semakin kecil karena adanya alokasi untuk melunasi hutang (Al-Najjar, 2012).

Kebijakan hutang perusahaan pada titik tertentu mengakibatkan penurunan nilai perusahaan. Tingginya rasio hutang mengindasikan tingkat risiko yang dihadapi perusahaan, baik beban bunga maupun angsuran pokok dimana akan mengurangi laba yang dihasilkan perusahaan sehingga investor lebih menjauhi perusahaan dengan DER yang tinggi. Preferensi berbeda, perusahaan dengan rasio hutang yang relatif tinggi cenderung 
memiliki kemampuan yang baik dalam mengendalikan risiko keuangan yang dihadapi sehingga dinilai positif oleh pasar dan nilai perusahaan meningkat (Ramadhani et al., 2018)

$\mathrm{H}_{1}$ : Leverage berpengaruh signifikan terhadap nilai perusahaan.

$\mathrm{H}_{2}$ : Leverage berpengaruh signifikan terhadap dividend policy

\section{Profitabilitas, Kebijakan Deviden dan Nilai Perusahaan}

Profitabilitas merupakan tingkat keuntungan bersih yang berhasil diperoleh perusahaan dalam menjalankan operasionalnya. Return on asset (ROA) diukur dari profitabilitas/ laba bersih setelah pajak (earning after tax) terhadap total investasinya yang mencerminkan kemampuan perusahaan dalam penggunaan investasi yang digunakan untuk operasi perusahaan dalam rangka menghasilkan profitabilitas perusahaan. Profitabilitas merupakan faktor terpenting yang dipertimbangkan oleh manajemen dalam dividend payout ratio (DPR). Semakin besar ROA menunjukkan kinerja perusahaan yang semakin baik, karena tingkat kembalian investasi (return) semakin besar. Seperti diuraikan sebelumnya, bahwa return yang diterima oleh investor dapat berupa pendapatan dividen dan capital gain, hal tersebut menjadi dasar untuk dirumuskan dalam hipotesis sebagai berikut: ROA berpengaruh positif terhadap DPR (Sartono, 2015).

Profitabilitas (ROA) menunjukkan kemampuan perusahaan dalam menghasilkan laba dengan memanfaatkan total asset yang dimilikinya. Sinyal positif yang ditunjukkan perusahaan melalui tingkat profitabilitas yang tinggi akan memberikan nilai bagi perusahaan, dimana perusahaan yang profitable akan memberikan sinyal pada pasar yang berupa informasi agar sinyal tersebut efektif, maka harus dapat ditangkap pasar dan dipersepsikan baik, serta tidak mudah ditiru oleh perusahaan yang berkualitas buruk (Putra \& Wiagustini, 2014).

Perusahaan yang mempunyai kemampuan yang tinggi dalam menghasilkan laba melalui pemanfaatan aset yang dimilikinya akan mempunyai kas yang besar pada tahun mendatang, hal tersebut akan membuat perusahaan untuk terus menempatkan dananya pada pos-pos investasi yang menguntungkan di masa mendatang. Profitabilitas yang tinggi menunjukkan prospek perusahaan baik, sehingga investor akan merespon positif sinyal tersebut dan nilai perusahaan akan meningkat, adanya pengaruh positif profitabilitas terhadap nilai perusahaan dapat dimungkinkan terjadinya sentimen positif pada para investor, sehingga harga saham meningkat, meningkatnya harga saham akan membuat nilai perusahaan juga meningkat.

$\mathrm{H}_{3}$ : Profitabilitas berpengaruh signifikan nilai perusahaan

$\mathrm{H}_{4}$ : Profitabilitas berpengaruh signifikan dividend policy

\section{Kebijakan Deviden dan Nilai Perusahaan}

Peningkatan dividen ini akan dapat memberikan pengaruh positif pada harga saham yang nantinya berpengaruh positif terhadap PBV (Irmawati, 2012). Nilai Perusahaan dapat dilihat dari kemampuan perusahaan membayar dividen. Besarnya dividen ini dapat mempengaruhi harga saham. Apabila dividen yang dibayar tinggi, maka harga saham cenderung tinggi sehingga nilai perusahaan juga tinggi. Sebaliknya bila jika dividen yang dibayarkan kecil maka harga saham perusahaan tersebut juga rendah. Kemampuan membayar dividen erat hubungannya dengan kemampuan perusahaan memperoleh laba. Jika perusahaan memperoleh laba yang besar, maka kemampuan membayar dividen juga besar. Oleh karena itu, dengan dividen yang besar akan meningkatkan nilai perusahaan. $\mathrm{H}_{5}$ : kebijakan deviden berpengaruh signifikan nilai perusahaan 


\section{METODE PENELITIAN}

Penelitian dilakukan pada perusahaan foods and beverages di Bursa Efek Indonesia. Populasi penelitian ini sejumlah 31 emiten foods and beverages. Objek dalam penelitian ini adalah laporan keuangan perusahaan. Metode penentuan sampel yang dipergunakan adalah purposive sampling dengan kriteria perusahaan yang tidak delisting dan membagikan dividen selama periode pengamatan tahun 2017 - 2019 sehingga diperoleh sampel sebanyak 19 perusahaan. Teknik analisis yang dipergunakan adalah path analysis.

Adapun variabel dalam penelitian ini,

1) Leverage yang diukur dengan debt to equity ratio (DER)

2) Profitabilitas yang diukur dengan return on assets (ROA)

3) Dividend Policy yang diukur dengan dividen payout ratio (DPR)

4) Nilai Perusahaan yang diukur dengan price to book value (PBV)

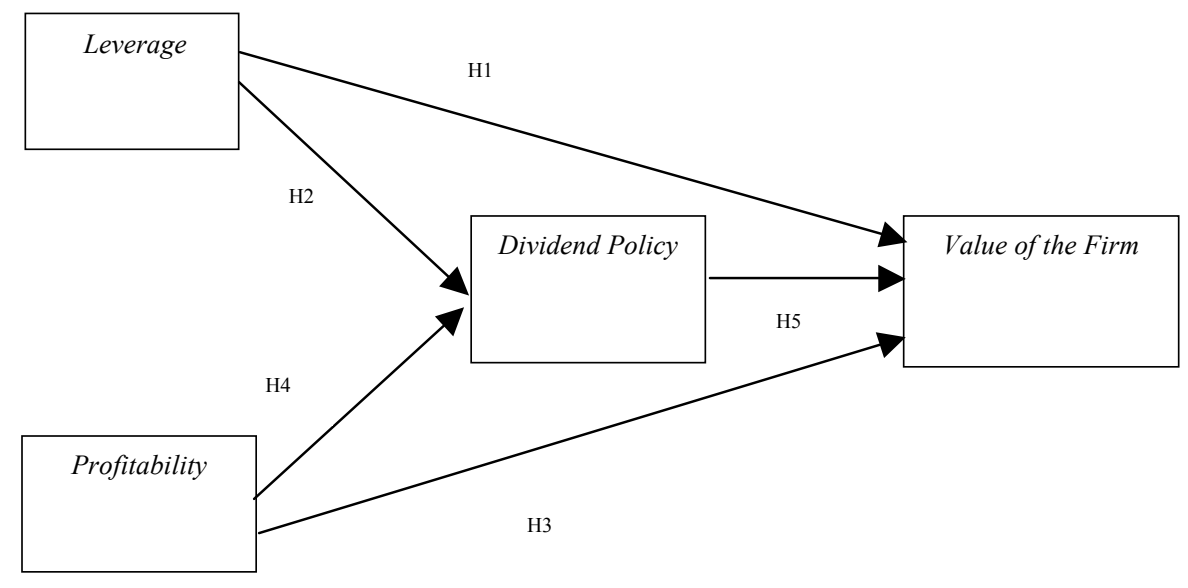

\section{Gambar 1.1 Model Penelitian}

\section{HASIL PENELITIAN DAN PEMBAHASAN}

Berdasarkan hasil analisis, dapat dijelaskan,

1) Hasil pengujian pada pengaruh leverage terhadap nilai perusahaan diperoleh nilai uji $t$ sebesar 3,946 dan taraf signifikansi sebesar 0,000. Hipotesis yang diajukan $\left(\mathrm{H}_{1}\right)$ dapat diterima apabila nilai t hitung $>\mathrm{t}$ tabel. Nilai $\bar{\alpha}=0,05$ dan nilai t tabel sebesar 2,005. Nilai $\mathrm{t}$ hitung $=3,946>\mathrm{t}$ tabel $=2,005$ serta taraf signifikansi sebesar $0,000<0,05$ menunjukkan bahwa leverage berpengaruh positif dan signifikan terhadap nilai perusahaan

2) Hasil pengujian pada pengaruh leverage terhadap dividend policy diperoleh nilai uji $\mathrm{t}$ sebesar -2,697 dan taraf signifikansi sebesar 0,009. Hipotesis yang diajukan $\left(\mathrm{H}_{2}\right)$ dapat diterima bila nilai $\mathrm{t}$ hitung $>\mathrm{t}$ tabel. Nilai $\bar{\alpha}=0,05$ dan nilai $\mathrm{t}$ tabel sebesar 2,005 . Nilai $\mathrm{t}$ hitung $=-2,697<\mathrm{t}$ tabel $=2,005$ serta taraf signifikansi sebesar $0,009<0,05$ menunjukkan bahwa leverage berpengaruh negatif dan signifikan terhadap dividend policy

3) Hasil pengujian pada pengaruh profitabilitas terhadap nilai perusahaan diperoleh nilai uji t sebesar 16,086 dan taraf signifikansi sebesar 0,000. Hipotesis yang diajukan $\left(\mathrm{H}_{3}\right)$ dapat diterima bila nilai $\mathrm{t}$ hitung $>\mathrm{t}$ tabel. Nilai $\bar{\alpha}=0,05$ dan nilai $\mathrm{t}$ tabel sebesar 2,005 . Nilai $\mathrm{t}$ hitung $=16,086>\mathrm{t}$ tabel $=2,005$ serta taraf signifikansi sebesar $0,000<0,05$ menunjukkan bahwa profitabilitas berpengaruh positif dan signifikan terhadap nilai perusahaan 
Tabel 1.1 Pengujian Direct Effect I

\begin{tabular}{|l|c|c|c|c|c|}
\hline Model & \multicolumn{2}{|c|}{$\begin{array}{c}\text { Unstandardized } \\
\text { Coefficients }\end{array}$} & $\begin{array}{c}\text { Standardized } \\
\text { Coefficients }\end{array}$ & $\mathrm{t}$ & Sig. \\
\cline { 2 - 5 } & $\mathrm{B}$ & Std. Error & Beta & & \\
\hline (Constant) & $-7,903$ & 2,476 & & $-3,192$ &, 002 \\
Leverage & 6,957 & 1,763 &, 250 & 3,946 &, 000 \\
Probabilitas &, 451 &, 028 &, 818 & 16,086 &, 000 \\
Dividend Policy &, 023 &, 018 &, 063 & 1,262 &, 213 \\
\hline
\end{tabular}

Sumber : Hasil analisis data (2020)

4) Hasil pengujian pada pengaruh profitabilitas terhadap dividend policy diperoleh nilai uji t sebesar 3,210 dan taraf signifikansi sebesar 0,002. Hipotesis yang diajukan $\left(\mathrm{H}_{4}\right)$ dapat diterima apabila nilai $\mathrm{t}$ hitung $>\mathrm{t}$ tabel. Nilai $\bar{\alpha}=0,05$ dan nilai t tabel sebesar 2,005. Nilai $\mathrm{t}$ hitung $=3,210>\mathrm{t}$ tabel $=2,005$ serta taraf signifikansi sebesar $0,002<0,05$ menunjukkan bahwa profitabilitas berpengaruh positif dan signifikan terhadap kebijakan deviden.

5) Hasil pengujian pada pengaruh dividend policy terhadap nilai perusahaan diperoleh nilai uji t sebesar 1,262 dan taraf signifikansi sebesar 0,213. Hipotesis yang diajukan $\left(\mathrm{H}_{5}\right)$ dapat diterima apabila nilai $\mathrm{t}$ hitung $>\mathrm{t}$ tabel. Nilai $\bar{\alpha}=0,05$ dan nilai $\mathrm{t}$ tabel sebesar 2,005 . Nilai $\mathrm{t}$ hitung $=1,262<\mathrm{t}$ tabel $=2,005$ serta taraf signifikansi sebesar $0,213>$ 0,05 menunjukkan bahwa dividend policy berpengaruh positif tidak signifikan terhadap nilai perusahaan.

Tabel 1.2 Pengujian Direct Effect II

\begin{tabular}{|l|r|r|r|r|r|}
\hline Model & \multicolumn{2}{|c|}{$\begin{array}{c}\text { Unstandardized } \\
\text { Coefficients }\end{array}$} & $\begin{array}{c}\text { Standardized } \\
\text { Coefficients }\end{array}$ & \multicolumn{1}{c|}{$\mathrm{t}$} & \multirow{2}{*}{ Sig. } \\
\cline { 2 - 4 } & \multicolumn{1}{|c|}{$\mathrm{B}$} & \multicolumn{1}{|c|}{ Std. Error } & \multicolumn{1}{c|}{ Beta } & & \\
\hline Leverage & $-33,388$ & 12,381 &,- 445 & $-2,697$ &, 009 \\
Probabilitas &, 617 &, 192 &, 414 & 3,210 &, 002 \\
\hline
\end{tabular}

Sumber : Hasil analisis data (2020)

6) Hasil pengujian Pengaruh leverage terhadap Nilai Perusahaan melalui mediasi dividend policy menggunakan Uji Sobel. Uji sobel akan menghasilkan standar error dari pengaruh tidak langsung leverage terhadap nilai perusahaan melalui dividend policy sebesar 0,096 dan nilai Z sebesar 3,946. Nilai Z hitung sebesar 3,946 mengindikasikan bahwa leverage berpengaruh positif dan signifikan terhadap nilai perusahaan melalui mediasi kebijakan deviden, hal tersebut dikarenakan nilai $\mathrm{Z}$ hitung 3,946 lebih besar (>) dari nilai $\mathrm{Z}$ tabelnya yaitu sebesar 1,96 .

7) Hasil pengujian Pengaruh profitabilitas terhadap Nilai Perusahaan melalui mediasi dividend policy menggunakan Uji Sobel, diperoleh nilai tidak langsung profitabilitas terhadap nilai perusahaan melalui dividend policy sebesar 0,100 dan nilai $\mathrm{Z}$ sebesar 16,086. Nilai $Z$ hitung sebesar 16,086 mengindikasikan bahwa profitabilitas berpengaruh positif dan signifikan terhadap nilai perusahaan melalui mediasi dividend policy, hal tersebut dikarenakan nilai $\mathrm{Z}$ hitung 16,086 lebih besar $(>)$ dari nilai $\mathrm{Z}$ tabelnya yaitu sebesar 1,96 . 


\section{Pembahasan}

1) Pengaruh Leverage Terhadap Nilai Perusahaan Foods and Beverages di Bursa Efek Indonesia periode $2017-2019$.

Variabel leverage diproksikan dengan debt to equity ratio (DER) berpengaruh positif dan signifikan terhadap nilai perusahaan. Pengaruh DER terhadap nilai perusahaan didukung oleh teori signalling, dimana besarnya hutang yang dipakai untuk modal perusahaan akan menambah jumlah kewajiban yang harus dilunasi (Sartono, 2015 : 96). Hasil penelitian ini sejalan dengan (Ramadhani et al., 2018) tingginya DER akan mencerminkan penggunaan hutang yang relatif tinggi. Semakin tinggi penggunaan hutang, investor menilai bahwa perusahaan memiliki kemampuan mengendalikan risiko keuangan yang dihadapi sehingga nilai perusahaan meningkat.

2) Pengaruh Leverage terhadap dividend policy pada perusahaan Foods and Beverages di Bursa Efek Indonesia periode 2017 - 2019.

Variabel leverage di proksikan dengan debt to equity ratio (DER) berpengaruh negative dan signifikan terhadap kebijakan deviden. Leverage berpengaruh negatif karena total hutang yang tinggi mengakibatkan pembagian deviden yang rendah. Hasil penelitian sejalan dengan (Mehta, 2012) serta (Putra \& Wiagustini, 2014) leverage berpengaruh negatif dan signifikan terhadap kebijakan deviden. Dimana leverage mencerminkan proporsi besarnya total hutang jangka Panjang dengan modal sendiri. Hutang yang semakin besar menyebabkan beban perusahaan menjadi besar karena beban biaya hutang yang harus ditanggung. (Al-Najjar, 2012) semakin besar hutang akan menyebabkan prioritas perusahaan untuk membayar dividend akan semakin kecil karena keuntungan perusahaan berkurang dengan adanya biaya hutang perusahaan.

dalam penelitian yang dilakukan bersifat signifikan.

3) Pengaruh Profitabilitas Terhadap Nilai Perusahaan Foods and Beverages di Bursa Efek Indonesia periode $2017-2019$.

Variabel Profitabilitas di proksikan dengan return on assets (ROA) dalam penelitian ini menunjukkan bahwa terdapat pengaruh positif dan signifikan terhadap nilai perusahaan. Hasil penelitian ini mendukung teori profitabilitas dimana perusahaan yang tingkat keuntungannya besar akan memberikan peningkatan pada kepercayaan pasar, sehingga akan meningkatkan nilai perusahaan. Hasil penelitian ini sejalan dengan (Mustapha \& Chyi, 2012), (Putra \& Wiagustini, 2014), (Ahmed, 2015), (Ramadhani et al., 2018), (Nandita \& Kusumawati, 2018) serta (Husna \& Satria, 2019) dengan peningkatan profitabilitas maka investor menerima signal bahwa perusahaan memiliki kinerja yang baik sehingga meningkatkan nilai perusahaan.

4) Pengaruh Profitabilitas Terhadap dividend policy pada perusahaan Foods and Beverages di Bursa Efek Indonesia periode 2017 - 2019.

Variabel profitabilitas diproksikan dengan return on assets (ROA) berpengaruh positif dan signifikan terhadap dividend policy. Hasil ini bermakna bahwa, semakin tinggi tingkat ROA yang dihasilkan dalam operasional perusahaan maka akan meningkatkan proporsi pembagian dividen. ROA adalah tingkat keuntungan bersih yang berhasil diperoleh perusahaan dalam menjalankan operasionalnya. Profitabilitas merupakan faktor terpenting yang dipertimbangkan oleh manajemen dalam dividend payout ratio. Semakin besar ROA menunjukkan kinerja perusahaan semakin baik, karena tingkat kembalian investasi (return) semakin besar dan laba yang dihasilkan sehingga pembagian deviden kepada pemegang saham lancar. Secara manajerial, ROA merupakan kemampuan perusahaan dalam menghasilkan laba. Hasil penelitian sejalan dengan (Al- 
Najjar, 2012) serta (Sukmawardini \& Ardiansari, 2018) yang menemukan profitabilitas berpengaruh positif dan signifikan terhadap kebijakan deviden.

5) Pengaruh dividend policy terhadap Nilai Perusahaan Foods and Beverages di Bursa Efek Indonesia periode $2017-2019$.

Kebijakan deviden (dividend policy) yang diproksikan dengan dividend payout ratio $(D P R)$ berpengaruh positif tidak signifikan terhadap nilai perusahaan. Hasil ini merupakan temuan penelitian, dimana secara umum pembayaran dividen kepada pemegang saham akan menimbulkan citra positif yang mampu meningkatkan nilai perusahaan. Berbeda dengan hasil penelitian ini, kebijakan yang diterapkan oleh perusahaan terkait pembagian dividen, tidak serta merta berdampak terhadap peningkatan nilai perusahaan. Hal ini mengindikasikan bahwa DPR yang rendah tidak sesuai dengan tujuan perusahaan yaitu kemakmuran pemegang saham dengan tujuan perusahaan yang tidak terpenuhi maka nilai perusahaan tidak meningkat. Hal ini sejalan dengan penelitian yang dilakukan oleh (Eldomiaty, 2012) peningkatan kebijakan deviden dengan proksi DPR tidak berdampak signifikan terhadap nilai perusahaan.

6) Pengaruh Leverage Terhadap Nilai Perusahaan Melalui Mediasi Kebijakan Deviden (dividend policy) pada perusahaan Foods and Beverages di Bursa Efek Indonesia periode $2017-2019$.

Kebijakan deviden yang di proksikan dengan dividend payout ratio (DPR) ditermukan mampu memediasi dalam pengaruh leverage terhadap nilai perusahaan (PBV). Pola mediasi dalam hubungan ini adalah mediasi parsial (sebagian). Semakin meningkat penggunaan laba maka akan meningkatkan ketersediaan dana yang dapat dipergunakan perusahaan dalam operasional usaha. Hal ini akan meningkatkan nilai perusahaan. Kontrasnya, peningkatan proporsi penggunaan hutang sampai pada batas tertentu, akan semakin memperbesar pengurangan proporsi laba yang akan dibagikan dalam bentuk dividen.

7) Pengaruh Profitabilitas Terhadap Nilai Perusahaan Melalui Mediasi Dividend Policy pada perusahaan Foods and Beverages di Bursa Efek Indonesia periode 2017 - 2019.

Dividend Policy diproksikan dengan dividend payout ratio (DPR) ditemukan mampu memediasi dalam interaksi profitabilitas terhadap nilai perusahaan. Pola mediasi dalam hubungan ini adalah mediasi parsial (sebagian). Semakin meningkat besaran laba yang dihasilkan perusahaan akan sebanding dengan peningkatan proporsi pembagian dividen perusahaan. Dengan peningkatan ini maka pasar akan merespon positif atas kinerja perusahaan sehingga nilai perusahaan meningkat.

\section{SIMPULAN}

Berdasarkan hasil penelitian maka dapat disimpulkan atas penelitian yang dilakukan pada perusahaan Foods and Beverages di Bursa Efek Indonesia periode 2017 - 2019 antara lain, leverage berpengaruh positif signifikan terhadap nilai perusahaan, leverage berpengaruh negatif signifikan terhadap dividend policy, profitabilitas berpengaruh positif signifikan terhadap nilai perusahaan, profitabilitas berpengaruh positif signifikan terhadap dividend policy dan secara langsung dividend policy berpengaruh positif tidak signifikan terhadap nilai perusahaan. Adapun temuan dalam penelitian ini, dividend policy mampu memediasi leverage terhadap nilai perusahaan dan profitabilitas terhadap nilai perusahaan dengan katagori mediasi parsial (sebagian).

Implikasi penelitian ini, investor dapat mencermati pola interaksi profitabilitas dan dividend policy perusahaan dalam penentuan nilai perusahaan sehingga dapat dijadikan dasar dalam menilai kinerja sebuah perusahaan. 
Keterbatasan penelitian ini hanya mengkaji variabel keuangan yang merupakan faktor internal perusahaan. Penelitian selanjutnya diharapkan memperluas kajian dengan mempertimbangkan faktor eksternal perusahaan diantaranya nilai tukar dan suku bunga.

\section{DAFTAR PUSTAKA}

Ahmed, Saghir. 2015. Critical Analysis of the Factors Affecting the Dividend Payout: Evidence from Pakistan. International Journal of Economics, Finance and Management Sciences. Vol 03 No.03 ISSN: 2326-9553

Al-Najjar, Basil. 2012. Devidens Behaviour And Smoothing New Evidence From Jordanian panel data. University of the West of England, Vol 1, hal 1-27

Arifin, Jauhar. 2016. The Influence of Intellectual Capital on Financial Performance of Bank Sector Companies Listed at Jakarta Stock Exchange in Periode 2008 - 2012. Jurnal AdBispreneur Vol.1, No.3, p.195-206

Brigham, F.E dan Houston, F.J, 2019. Fundamentals of Financial Management, $15^{\text {th }}$ Edition. Cengage Learning

Eldomiaty, Tarik Ibrahim. 2012. Market Risk Adjusted Dividend Policy and Price to Book Ratio. British University in Egypt, Faculty of Business Administration, Economics and Political Science

Fahmi, Irham. 2014. Manajemen Keuangan Perusahaan dan Pasar Modal. Mitra Wacana Media Jakarta.

Fakhruddin, Hendy M dan Hadianto. 2008. Istilah Pasar Modal A-Z. Jakarta: Elex Media

Gordon, Myron and Litner, John. 1956. Distribution of Income of Corporations Among Dividend, Retained Earning and Taxex. The American Economic Review.

Harmono, 2014, Manajemen Keuangan: Berbasis Balance Scorecard Pendekatan Teori, Kasus dan Riset Bisnis, PT Bumi Aksara, Jakarta.

Husna, Asmaul and Satria, Ibnu. 2019. Effect of Return on Asset, Debt to Asset Ratio, Current Ratio, Firm Size and Dividend Payout Ratio on Firm Value. International Journal of Economics and Financial Issues, Vol.9, Iss.5, pp.50-54

Irmawati, Dessy. 2012. Analisis Pengaruh Struktur Modal, Kepemilikan Saham Manajemen, Profitabilitas, Ukuran Perusahaan, Dan Likuiditas, Terhadap Kebijakan Dividen Dalam Meningkatkan Nilai Perusahaan (Studi pada Industri Manufaktur di Bursa Efek Indonesia Periode Tahun 2008-2011). Tesis. Universitas Diponegoro.

Kasmir. 2014. Analisis Laporan Keuangan. Jakarta : Rajawali Pers.

Litzenberger, Robert H, and Ramaswamy, Krishna. 1979. The effect of personal taxes and dividends on capital asset prices: Theory and empirical evidence. Journal of Financial Economics. Vol. 7, Iss 2, pp. 163-195

Mehta, Anupam. 2012. An empirical analysis of determinants of dividend policy evidence from the UAE companies. Global Review of Accounting and Finance, Vol 1, hal 1-48

Modigliani, F dan Miller, M. H. 1961. Dividend Policy, Growth and the Valuation of Shares. The Journal of Business. Vol.34, 411

Mustapha, Marina and Chyi, Ng Huey. 2012. Determinants of Firm Leverage and Cash Flow Relationship. Taylor Business School. Vol.1, pp.76-98

Nandita, Asna dan Kusumawati, Rita. 2018. Pengaruh Profitabiitas, Leverage, Size dan Kebijakan Dividen terhadap Nilai perusahaan. Change Angent for Management Journal, Vol.2, No.2 
Noerirawan, Moch. Roni dan Muid, Abdul. 2012. Pengaruh Faktor Internal dan Eksternal Perusahaan terhadap Nilai Perusahaan (Studi Empiris pada Perusahaan Manufaktur yang terdaftar si Bursa Efek Indonesia Periode 2007-2010. Diponegoro Journal of Accounting. Vol.1, No,1,pp.582-593

Putra, I Wayan Juniastina dan Wiagustini, Ni Luh Putu. Pengaruh Leverage dan Profitabilitas Terhadap Kebijakan Dividen dan Nilai Perusahan. E-Jurnal Manajemen, [S.1.], v. 3 , n.9, sep. 2014. ISSN 2302-8912.

Ramdhani, Akhmadi dan Kuswantoro, M. 2018. Pengaruh Leverage dan Profitabilitas terhadap Nilai Perusahaan dengan Kebijakan Dividen sebagai Variabel Intervening. Jurnal Riset Bisnis dan Manajemen Tirtayasa, Vol.2, No.1, 21-43

Ross, Stephen. 1977. The Determination of Financial Structure : The Incentive-Signalling Approach. Bell Journal of Economics. Vol.8, Issue 1, 23-40

Sartono, Agus. 2015. Manajemen Keuangan : Teori dan Aplikasi. Edisi Keempat. Yogyakarta : BPFE

Sukmawardini, Dewi and Ardiansari, Anindya. 2018. The Influence of Institusional Ownership, Profitability, Liquidity, Dividend Policy, Debt Policy on Firm Value. Management Analysis Journal.Vol.7, No.2, pp.211-222

Wiagustini, Ni Luh Putu. 2014. Manajemen Keuangan. Udayana University Press

www.idx.co.id. 